\title{
Yaşlılık Deneyimi ve Kesişimsellik: İstanbul Örneği
}

\author{
DOI: $10.26466 /$ opus.693033
}

*

\author{
Berfin Varıșlı * \\ * Dr. Öğr. Üyesi, Maltepe Üniversitesi, İnsan ve Toplum Bilimleri Fakültesi, İstanbul/Türkiye \\ E-Posta: berfinvarisli@maletpe.edu.tr ORCID: 0000-0001-5051-9546
}

\begin{abstract}
Öz
Bu çalışma kentlileşme ve yaşlılık kesişimselliğinden yola çıkarak İstanbul'un Sancaktepe ve Şişli ilçelerinde yaşayan yaşlı bireylerin yaşlılık deneyimlerinin farklılaşmasını konu almaktadır. Gelir ve kentleşme seviyesi, göç öyküsü ve demografik yapı bakımından birbirinden oldukça farklı iki ilçenin yaş almış bireyleri aynı zamanda ve aynı kentte iki farklı yaşlılık deneyiminin de özneleri olmaktadır. Yaşın ilerlemesi ile birlikte yillar boyunca kazanılan deneyimler bireylerin yaşamlarında önemli etkiler yaratmaktadır. Kesişimsellik prensibi ile yapılan araştırmalar, tüm bu deneyimlerin bireylerin kişisel özellikleri de göz önüne alındığında önce birbiriyle, sonrasında topyekûn etkileşimini anlamak için faydal bir bakış açısı ortaya koymaktadır. Niteliksel araştırma yönteminin uygulandı̆̆ı saha araştırmasında Sancaktepe ve Şişli ilçelerinde belirli aralıklarla gerçekleştirilen 45 derinlemesine görüşme ve bu görüşmelerden elde edilen bulgular, sosyo-ekonomik statü, geleneksellik ve yalnızlik kavramlar temelinde kategorize edilmiştir. Sonuçlar geleneksellik ve modernitenin yaşlı bireyin yaşamında ne denli önemli olduğunu ortaya koyar niteliktedir. Yaşlılık deneyiminin toplumsal yapı, habitus ve aile ilişkileri ile yakından ilişkili olduğu da ortaya çıkmıştır.
\end{abstract}

Anahtar Kelimeler: Yaşlılık deneyimi, kentlileşme, yalnızlık, kesişimsellik 


\title{
Old Age Experience and Intersectionality: Istanbul Example
}

\begin{abstract}
This study is about the differentiation of old age experiences of individuals, who are over 65 years, living in Şişli and Sancaktepe districts of Istanbul by departing from the intersectionality of urbanisation and old age. Elderly individuals of two districts that are quite different from each other in terms of income and urbanization level, migration history and demographic structure are also subjects of two different aging experiences in the same city. Years of experience with the advancement of age have significant effects on individuals' lives. The researches carried out with the intersectionality principle reveal a useful perspective to understand the interaction of all these experiences with each other and then the overall interaction. In the field research where qualitative research method was applied, 45 in-depth interviews were conducted in Sancaktepe and Şişli periodically and the findings were categorized on socio-economic status, traditionality and loneliness concepts. The results indicate how important traditionality and modernity are in the life of the elderly. It is also revealed that the old age experience is closely related to social structure, habitus and family relations.
\end{abstract}

Keywords: Ageing experience, urbanism, loneliness, intersectionality 


\section{Giriş}

Geleneksellik ve modernite arasında sosyal, siyasal ve kültürel olarak konumlanan Türkiye'de yaşlı nüfusun kamusal alanda daha çok var olması, toplumun yaşlıya bakış açısını şekillendirmiş; yaşlının başta ailesi, yakın çevresi, toplumsal gruplarla ve toplumun geneliyle etkileşimini anlamak için özellikle son yıllarda artan oranda çalışmalar yapılmaya başlanmıştır. Birleşmiş Milletler verilerine göre dünyada 60 yaş üstü nüfus 2017 yılında 962 milyon iken, 2050 yılında bu rakamın ikiye katlanarak 2.1 milyar olması beklenmektedir (UN-WPA, 2017). Türkiye nüfusu da bu küresel demografik değişime paralel olarak yaşlanmaktadır. 2018 yılı itibariyle ülkemizde 65 yaş üstü nüfusun toplam nüfusa oranı \% 8.8 iken bu oranın 2023'te \%10.2, 2030' da \%12.9, 2060'ta ise \%22.6'ya ulaşılacağ ön görülmektedir (TÜİK, 2018). Bu hızlı değişime ayak uydurmak için Türkiye'de yerel ve ulusal politikaların şekillendirilmesi gerekmektedir. Ülkemizde, kalkınma stratejileri içerisinde yaşlılık konusu genellikle emeklilik ve yaşlı nüfusun sağlı̆̆ı bağlamında değerlendirilirken, yaşlılık ve göç, yaşlı istihdamı, yaşlı hakları gibi konuları başta sosyolojinin olmak üzere, psikoloji, felsefe, ekonomi, politika gibi pek çok bilim dalından bilim insanlarının çalıştıkları konular arasında yerini almaya başlamıştır. Bu çalışma 15 milyonu aşan nüfusuyla Türkiye'nin nüfus yoğunluğu en yükssek kenti olan İstanbul'da yaşayan yaşlıların yaşlılık deneyimlerini kesişimsellik temelinde analiz etmeyi amaçlamaktadır. ${ }^{1} \mathrm{Bu}$ amaca ulaşmak için 2015-2017 yılları arasında, İstanbul'un demografik olarak karşılaştırmaya uygun, farklı modernleşme, kentleşme, göç süreçlerini yaşamış iki ilçesi olan Şişli ve Sancaktepe'de 45 kişiyle derinlemesine görüşmeler yapılmıştır. Bu görüşmelerde cinsiyet, göç deneyimi, dünya görüşü, aile yapısı, sosyo-ekonomik statüsü, medeni durum gibi etkenlerin kesişimselliği araştırılarak İstanbul'daki değişen yaşlılık deneyimleri ele alınmaktadır.

\section{Yaşlılık Deneyimi ve Kesişimsellik Paradigması}

Bireyi tek bir özelliğiyle değil, birden fazla özelliğinin birbiriyle ortaya koyduğu ilişkiyi analiz etmek için ilk kez 1991 yılında ABD’li hukukçu Kimberlé

\footnotetext{
1 Bu çalışma, yazarın 2017 yılında Maltepe Üniversitesi Sosyal Bilimler Enstitüsü Sosyoloji A.B.D'ında tamamladığı "Katmerli Ayrımcılık: 65 Yaş Üstü Kişilerle Yapılan Niteliksel Araştırma, İstanbul, Sancaktepe ve Şişli, 2015-2016" başlıklı yayımlanmamış doktora tezinin kimi bulgularından derlenmiştir.
} 
Crenshaw tarafından ortaya atılan kesişimsellik paradigması, yaş, cinsiyet, medeni durum, gelir seviyesi gibi özelliklerin birbiriyle etkileşimini ifade eder. Dolayısıyla, bireyin ya da toplumun yaşlılık sürecinin bireysel ve toplumsal dinamiklerini anlamak için kesişimsellik paradigmasını kullanmak tercih edilebilir. Bireyin yaşam biçimi, tercihleri, mekân seçimi ve kullanımı, toplumun diğer bireyleri ile ilişkilerini ifade eden ve hangi yaşta olursa olsun o yaşın, dönemin hayata ilişkin ana hatlarını ortaya koyan yaşam aranjmanlarını anlayabilmek için kesişimsel bir bakış açısına ihtiyaç vardır.

Yaşam aranjmanı kavramı ise yaş, cinsiyet, gelir ve eğitim durumu, medeni durumu gibi etkenlerin ilişkiselliğidir (Kalaycıŏlu ve ark., 2003, s.15). Dolayısıyla bu kavramların ilişkiselliği ve/veya kesişimselliği yaşlılıkta belki de yeniden şekillenecek olan yaşam aranjmanlarını etkilemektedir. Böylelikle kesişimsellik hem yaşlılık deneyiminin karmaşık etki alanını bireysel ve toplumsal dinamikleri açısından gözler önüne sererken yaşam aranjmanı kavramının ifade ettiği ilişkiselliği de içerir. Bourdieu'nün (1997) habitus kavramı da gerek yaşam aranjmanları gerekse yaşam deneyimi kavramlanı ile ilişkiseldir. Pierre Bourdieu, habitus kavramın "bireysel olanın dahi toplumsal, kolektif olduğunu ortaya koymaktır" şeklinde açıklamıştır (Bourdieu, 2003, s.116). Dolayısıyla habitus hem bireyin kimliğini oluşturan faktörleri şekillendirir hem de bireyin ait olduğu toplumsal grubun özelliklerini barındırır. Bu nedenle habitus, bireyin tercihleri, beğenileri, etkileşimleri bağlamında yaşl1lık deneyimini ve yaşam aranjmanlarını da belirler.

\section{İstanbul'da Yaşlı Olmak}

İstanbul'da, Türkiye İstatistik Kurumu'nun 2018 verilerine göre 65 yaş üstü nüfus 1.006,545 iken kentin nüfusu 15.067.000'dir. Dolayısıyla 65 yaş üstü nüfusun kentin toplam nüfusuna oranı 2018 yılı itibariyle \% 6.67'dir (TÜİK, 2018). Bununla birlikte, İstanbul'un, tıpkı Türkiye'nin olduğu gibi Asya ile Avrupa arasındaki "arafta" olarak betimlenebilecek coğrafi konumlanışının sosyal ve kültürel pek çok yansıması bulunmaktadır. 15 milyonu aşan nüfusuyla İstanbul, Türkiye'nin nüfus yoğunluğu en yüksek kenti olmakla birlikte ülkemizin küçük bir modeli gibidir. İstanbul, çokkültürlü yapısı, içerdiği ekonomik ve kültürel ağlar ve bu ağlardaki bireylerin sosyo-kültürel çeşitliliği, Türkiye'nin kültürel mozaiğinin örneğidir. Türkiye'de özellikle 1980'ler- 
den sonra yaşanan toplumsal değişim, İstanbul özelinde somut biçimde analiz edilebilmektedir. Küreselleşme ve hızlı pazar ağlarının artışıyla İstanbul ayrıca farklı toplumsal grupların ortaya çıkışına da tanıklık etmiştir (Keyder, 2005, s.124).

Araştırmanın saha çalışması için Şişli ve Sancaktepe ilçelerinin seçilmesinin nedeni bu iki ilçede yaşayan bireylerin sosyo-ekonomik ve sosyo-kültürel açıdan farklı olmalarıdır. Şişli çoğunlukla orta ve üst sınıf, eğitimli Gayrimüslimler ve Müslümanların bir arada yaşadığı, kentli yaşam tarzının devam ettirildiği, sanayi ile işbirliği içinde olan bir ilçe iken Sancaktepe çoğunlukla alt ve orta sınıftan ve geleneksel yaşam biçimini sürdüren Sünnilerin ve Alevilerin yoğunlukla yaşadığı bir ilçedir (İTO, 2011). Şişli'de yaşayanların çoğunluğu doğma büyüme İstanbullu iken Sancaktepe'de yaşayan bireylerin çoğu ilçeye Türkiye'nin farklı bölgelerinden göç etmiştir. Kentleşme sürecini devam ettiren Sancaktepe iç göçün cazibe merkezi olan bir ilçedir. Anadolu'nun pek çok kentinden Sancaktepe'ye göç devam etmektedir.

\section{Yöntem}

Araştırmanın örneklemini Sancaktepe ve Şişli'de yaşayan, yaşam biçimi, dünya görüşü ve sosyo-ekonomik statü ve eğitim durumu bakımından farklılık gösteren 65 yaş üstü İstanbullular oluşturmaktadır. Niteliksel araştırma yönteminin kullanıldığı bu araştırmada, 45 derinlemesine görüşme yapılmış, görüşülen kişilere kartopu tekniğiyle ulaşılmıştır. Öncelikle her iki ilçeden üçer mahalle seçilmiş ve bu mahallelerde yaşayan bireyler sosyo-ekonomik statülerine göre kategorize edilmiştir. Görüşülen kişilerin cinsiyet dağıllmında da denge gözetilmeye çalışılmıştır. Her ne kadar sosyo-ekonomik statü konusunda tam anlamıyla eşit dağılım olmasa da cinsiyet farklılığında dengeli dağılım yakalanmıştır.

Yaş sinıflandırmasında Dünya Sağlık Örgütünün belirlediği yaş aralıkları gözetilmiş, 65-74, 75-84 ve 85 üstü yaş grupları ile görüşmeler gerçekleştirilmiştir.

Aşağıda, derinlemesine görüşmeler yapılan kişilerin demografik özellikleri yer almaktadır. Görüşülen kişilerin çoğunluğu genç yaşlı ve evlidir ve Sünni Müslüman'dır. İstanbul'da yaşama sürelerine bakıldığında katılımc1ların çoğunun kentlileşme deneyimini içselleştirdikleri, uzun süredir İstanbul'da yaşadıkları görülmektedir. Bu ortak noktalara karşın sosyo-ekonomik 
statü, eğitim durumu, gelir düzeyi gibi değişkenler görüşülen kişiler arasındaki farklılıkları ortaya koymaktadır. Bu farklılıklar, araştırma sorusunu oluşturan yaşlılık deneyimi, yalnızlık ve geleneksellik temalarındaki görüş, bakış açısı ve duygu farklılıklarını ortaya koymaktadır. Niteliksel araştırma yönteminin doğası gereği araştırma bulguları araştırma yapılan yıllarda ve görüşülen kişilerin duygu ve düşüncelerini ortaya koymaktadır.

Tablo 1. Katılımcılarn Demografi Özellikleri

\begin{tabular}{|c|c|c|c|}
\hline \multirow[b]{2}{*}{ Kişisel Özellikler } & & \multirow{2}{*}{$\begin{array}{l}\text { Şişli } \\
\text { (Sayı) } \\
\end{array}$} & \multirow{2}{*}{$\begin{array}{l}\text { Sancaktepe } \\
\text { (Sayı) }\end{array}$} \\
\hline & & & \\
\hline \multirow{2}{*}{ Cinsiyet } & Erkek & 9 & 15 \\
\hline & Kadın & 11 & 10 \\
\hline \multirow{3}{*}{ Yaş } & Genç Yaşlı (65-74) & 12 & 12 \\
\hline & Orta Yaşlı (75-84) & 7 & 9 \\
\hline & İleri Yaşlı $(85+)$ & 1 & 4 \\
\hline \multirow{4}{*}{ Medeni Durumu } & Evli & 12 & 12 \\
\hline & Boşanmış & 2 & 1 \\
\hline & Dul & 3 & 11 \\
\hline & Hiç Evlenmemiş & 3 & 1 \\
\hline \multirow{3}{*}{ Sosyo-ekonomik Statü (SES) } & Üst & 7 & 4 \\
\hline & Orta & 8 & 6 \\
\hline & Alt & 5 & 15 \\
\hline \multirow{6}{*}{ Eğitim Durumu } & Okuma-yazma bilmiyor & 0 & 7 \\
\hline & İlkokuldan Terk & 2 & 1 \\
\hline & İlkokul Mezunu & 2 & 9 \\
\hline & Ortaokul Mezunu & 1 & 5 \\
\hline & Lise Mezunu & 6 & 2 \\
\hline & Yüksekokul Mezunu & 9 & 1 \\
\hline \multirow{4}{*}{ Din-Etnik Köken } & Rum & 2 & 0 \\
\hline & Ermeni & 3 & 0 \\
\hline & Alevi & 0 & 6 \\
\hline & Sünni & 15 & 19 \\
\hline \multirow{4}{*}{ İstanbul'da Yaşama Süresi } & Doğma büyüme & 14 & 3 \\
\hline & 0-9 Yil & 0 & 4 \\
\hline & 10-30 Yil & 1 & 11 \\
\hline & $31+Y_{11}$ & 5 & 7 \\
\hline \multirow[b]{2}{*}{ Yakınını kaybetmiş mi? } & Evet & 14 & 12 \\
\hline & Hayır & 6 & 13 \\
\hline
\end{tabular}

\section{Bulgular}

Bireyin yaşlılık deneyimi, kimliğinin yapı taşlarını oluşturan yaş, sosyo-ekonomik statü, cinsiyet, medeni durumu, kayıp öyküsü gibi pek çok özelliği ile 
şekillenmektedir. Dolayısıyla sosyolojinin farklı araştırma alanlarında olduğu gibi yaşlılık da kesişimsellik bakış açısıyla irdelenmesi gereken konuların başında gelmektedir. Birey yaş aldıkça kendi sosyal çevresi, alışkanlıkları da değişir. Eş zamanlı olarak ve içinde yaşadığı toplumdaki değişim de göz önüne alındığında yaşlanma deneyimi yeniden üretilirken, yaşlanma ve yaşlılık kavramları da yeni üretilen yapıyla birlikte yeniden değişir.

Birey yaş aldıkça ve içinde yaşadığı toplum değiştikçe yaşlanma deneyimi de dönüşür.

Bourdieu (1997) yaşlar arasındaki kategorizasyona karşı olduğunu, her bireyin diğerine göre yaşlı ya da genç olduğunu savunmaktadır. Ancak yine de yaşam aranjmanları göz önüne alındığında yaşam evreleri yelpazesinin her bir parçası birbirinden farklıdır. Gençlik, çocukluktan, yaşılılı gençlikten farklıdır. Ancak elbette ki bu farklılığı tetikleyen önemli etkenlerden biri de bireyin habitusudur. Habitus, bireyin beğenilerini, davranışlarını ve seçimlerini etkilediği gibi neredeyse tüm yaşamını da şekillendirmektedir. Ancak yaşlılıkta habitus kadar ve habitusla beraber, yaşanmışlıklar bir başka deyimle deneyimler de önem kazanmaktadır. Yaşlılık sürecinde de habitusun etkisi devam etmekle birlikte elde edilen deneyimlerin habitus ile kesişimi yaşlılık sürecindeki yaşam algısını da değiştirmektedir. Yaşlılık sürecini habitus ve deneyimlerin kesişimselliği açısından ele almak topyekûn etkileşimi anlamak adına faydalıdır. Deneyimlerin bireyin kişisel özellikleri ile de şekillendiği, bir kesişimsel durumun da deneyim ve kişisel özellikler arasında olduğu açıktır. Bu araştırmanın bulguları bu kavramsal çerçeveden yola çıarak irdelenmeye çalışılmıştır.

Araştırmada öne çkan bulgular, ilçelerin demografik farklılıkları ve değişim süreçleri göz önüne alındığında sosyo-ekonomik statü-yaşlılık deneyimi, geleneksel/modern ayrımı, kentleşme ve yalnızlık kavramları ekseninde analiz edilmiştir. Sosyo-ekonomik statü ve yaşlılık kesişimselliği bu çalışma için önemli görülmüştür çünkü bireyin sosyo-ekonomik statüsünün yaşam biçimi, gelecek beklentisi, sağlık, kültür sanat faaliyetleri gibi etkenlere ulaş1mını yakından etkilemektedir. Bununla beraber saha çalışması için seçilen Sancaktepe ve Şişli ilçelerinde yaşayan yaşlıların sosyo-ekonomik farklılıkları, farklı yaşlılık deneyimlerini anlamak için kolaylaştırıcıdır. Bu araştırmanın ikinci varsayımı, yaşlılık deneyimini şekillendiren bir ikinci kesişimselliğin geleneksel ve modern ayrımında ortaya çıtığıdır. Bu çalışmada söz konusu ayrımın hem toplumsal yapı hem de bireyin yaşam biçiminde ortaya 
çıktı̆̆ düşünülmüştür. Görece geleneksel bir toplumsal yapıya sahip Sancaktepe'deki yaşlıların görece modern bir yapıya sahip Şişli'deki yaşlılara nazaran farklı yaşam biçimi benimsedikleri, bu farklılığın da yaşlılık deneyimlerini etkilediği gözlemlenmiştir. Bu durum bulgular bölümünde detaylı bir şekilde analiz edilmiştir. Yaşlılık deneyimini şekillendiren bir üçüncü kavram kümesi olan kentleşme-bireyselleşme ve yalnızlık kavramlarının kesişimselliğidir. Bu kavramlar, yaşam evrelerinin pek çoğunda olduğu gibi yaşlılıkta da hem birbirleri ile ilişkiseldir, hem de bu çalışmanın kavramsal çerçevesini oluşturan diğer iki kavram kümesi ile etkileşim halindedir. Bir başka deyişle kentleşme, bireyselleşme ve yalnızlık kavramları hem birbirleri ile ilişkilidir, birbirlerini şekillendirirler; hem de sosyo-ekonomik statü-yaşlılık deneyimi ve geleneksel/modern ayrımı ile etkileşirler. Söz konusu etkileşimlerin, Sancaktepe ve Şişli özelindeki izdüşümü aşağıda yer almaktadır.

\section{Yaşlılık Deneyimi ve Sosyo-Ekonomik Statü}

65 yaş üstü bireyin yaşlılık deneyimi onun yaşlılık mefhumu ile ilişkilidir. Yaşlılık algısı, kronolojik yaştan bağımsız, öznel yaş ile ilintilidir. "Hissedilen yaş" ya da "sübjektif yaş" olarak da bilinen öznel yaş, yaşlı bireyin kendini konumlandırdığı, duygusal olarak kendini tanımladığı yaş grubunu anlatır (Settersten ve Mayer, 1997). Örnek olarak 60 yaşındaki birey kendini genç, 45 yaşındaki birey de kendini yaşlı hissedebilir. Saha araştırmasında bu durum ortaya çıkmış, öznel yaşın bireyin yaşlılık algısını belirlediği gözlemlenmiştir.

Öte yandan, sübjektif yaş kavramını, Bourdieu'nün düşünümsellik kavramı ile de açıklamak mümkündür. Düşünümsellik, Bourdieu'ye göre "bireysel olandaki toplumsalı, mahremin altında gizlenen gayri şahsiyi, özelin en derinine gömülmüş evrenseli keşfettirerek bizi böylesi yanılsamalardan kurtaran şeydir" (Bourdieu ve Wacquant, s. 40). Yaşlı bireyin bireysel olarak ifade ettiği pek çok şeyin toplumsal olduğunu, toplum tarafından yeniden üretildiğini söylemek mümkündür. Örneğin çoğunluğu Şişli'de yaşayan, aktif bir yaşlılık süreci geçiren, üst sosyo-ekonomik statüden, eğitim düzeyi yüksek bireyler, kendilerini yaşlı olarak tanımlamaktan kaçınmaktadırlar. Buna karşın çoğunluğu Sancaktepe'de geleneksel bir yaşam tarzı sürdüren, dindar yaşlılardan kendini yaşlı olarak tanımlayanlar, aynı zamanda yaşlılığı "onlara Allah tarafından verilmiş bir lütuf" olarak görmekte ve uzun yıllar 
yaşadıkları için şükretmektedirler. Dolayısıyla, araştırma yapılan Şişli ve Sancaktepe'de, farklılaşan toplumsal yapılar bireysel olanı etkilemiş, yaşlıların kendilerini algılama ve bunu dillendirme biçimlerini değiştirmiştir.

Öte yandan, Şişli'den orta ve üst sosyo-ekonomik statüdeki, yüksek eğitimli katılımcıların bir kısmı, yaşlıı̆̆ın çocukluk ve yetişkinlik gibi doğal bir evre olduğunu belirtmişlerdir. Bu katılımcılar yaşlılığı ölüm ile ilişkilendirmiş, ölüm kelimesini doğrudan telaffuz etmeseler de yaşlanmanın ölüme hazırlık olduğunu ifade etmişlerdir.

- "Yaşlanma...O da bir nimettir yaşlllık. Nasip etti bize Allah bu yaşları da yaşıyoruz..."(Eyüp, Sancaktepe, Erkek, 80)

- "Yaşlanmak mi...? Yaşlanmak, yaşamın doğal bir evresi olarak bir dönemi olarak görüyorum. Sonuçta yaşlanacağız, canlıyız." (Kadri, Şişli, Erkek, 74)

- "Hani her canl gibi... Başlayıp biten hayat var, bu hayatm bütün bir dönemi, sonraki dönem de ölüm." (Polat, Şişli, Erkek, 71).

Buna karşın eğitim düzeyi düşük, alt sosyo-ekonomik statüden katılımcıların çoğu aktif bir yaşlanma süreci geçirmedikleri belirtmişlerdir. Bu katılımclar hareketsiz ve sağlıklı beslenmeden uzak bir yaşam sürdürdüklerini dile getirmişlerdir.

- "Valla yaşlanmak... İhtiyarlamak, ihtiyarladıktan sonra da ölmek... Başka bir şey aklima gelmiyor." (Süleyman, Sancaktepe, Erkek, 65)

- "Valla Allah kimseyi el ayakta koymasin. Hanım rahat olsun da çocuklarm önünde, ben de bundan sonra ölümüme vah demem. E ne olacak? Ahiri ölümdür." (İsmail, Sancaktepe, Erkek, 72)

Öte yandan Sancaktepe'de yaşayan katılımcilar "gençlerin yaşlılara davranışını nasıl görüyorsunuz" sorusuna mahallelerinde yaşayan gençlerin onlara sevecen ve kibar davrandıklarını belirterek gençlerin onlara toplu taşımada yer verdiklerini, pazardan gelirken poşetlerini taşımaya yardımcı olduklarını, sokakta karşılaştıklarında birbirlerine selam verip hal hatır sordukların dile getirmişlerdir.

- "Kartımiz var, gideceğimiz yere gidiyoruz. Ben biniyorum, yer yoksa oradaki gençlerden birisi kalkıyor, otur diyor bizi. Yer veriyorlar." (Hülya, Sancaktepe, Kadın, 70)

Şişli'de yaşayan katılımcılar ise mahallede yaşayan gençleri tanımadıklarını ifade ederek gençlerin onlara saygı duymadıklarını söylemişlerdir. Bu duruma örnek olarak sokakta yürürken gençlerin onlara çarpıp geçtiklerini 
belirtmişler, toplu taşıma araçlarında da kendilerine yer verilmemesinden şikâyet etmişlerdir.

- "Mesela kızım diyelim yürüyorum şurda (kaldırımı gösteriyor). Tabi biz yavaş yürüyoruz biliyor musun? Napayım koşamam ya. Adam geliyor çarpıyor, dirsek atıp geçiyor nerdeyse." (Rezzan, Şişli, Kadın, 82)

- "Otobüsteyim veyahut durakta bekliyorum. Kalk bir yer ver değil mi? Deden yaşında adamım... Yok. Gözünü kapatıyor, beni kandıracak... Uyuyor gibi yapıyor aklınca..." (Ali, Şişli, Erkek, 78)

\section{Geleneksel/Modern Ayrımı}

Yaşlılık ve geleneksellik konusu son yıllarda pek çok araştırmacı tarafından farklı yönleriyle araştırılan bir konu olarak öne çımaktadır. Öte yandan, yaş kavramından azade olarak dini ritüelleri yerine getirmek pek çok birey için yaşamsal önemdedir. Bununla birlikte yaş ilerledikçe bireylerin muhafazakârlık seviyesinin arttı̆ını ve bireysel ya da topluluk içinde gerçekleştirilen dini ritüellere daha sık katıldıklarını ve dini kurallara uymaya daha çok dikkat ettiklerini göstermektedir (Barna, 2002; Blazer ve Palmore, 1976; Davie ve Vincent, 1998).

Yaşlanma ve din konusu ele alınırken kişiye ya da o dinin yapısına özel bir "öznel dindarlıktan" söz etmek gerekmektedir (Taylor, 1986). Bir topluma, toplumsal gruba ya da kişiye özel bir inanç durumu olarak da tanımlanabilecek "öznel dindarlık" kavramı bireyin kişisel özellikleri düşünüldüğünde kişiden kişiye farklılık gösterebilecek niteliktedir. Bir başka deyişle, "öznel dindarlık" cinsiyet, eğitim durumu, sosyo-ekonomik statü ve deneyimlerle değişebilen, akışkan bir kavram olarak yorumlanabilir. Bu çalışmada da görece geleneksel bir yaşam süren dindar bireylerin yaşadığı Sancaktepe ile görece moderniteye özgü bir yaşam tarzına sahip ve kendilerini laik olarak nitelendiren Şişlili yaşlıların yaşlılık deneyimleri arasındaki farklar ortaya çıkmıştır. Öncelikle Sancaktepeliler yaşlılık konusunda olumlu fikirlere sahiptir ve yaşl1lı̆̆ 1 bir "lütuf" olarak gördüklerini dile getirmişlerdir. Yaşlılıkla beraber oluşan hastalıklar onlar için "Allah tarafından verilen bir sınav"dır. Kendilerini "dindar" olarak nitelendiren bu kişiler, inançları sayesinde hastalıklar, güçsüzlük, yalnızlık gibi yaşlılık sürecinde karşı karşıya kaldıkları zorluklarla daha kolay baş ettiklerini belirtmektedirler. Bu katılım- 
cllar yaşl1lı̆̆ı, ölüme ve ölümden sonra var olduğuna inandıkları ahirete hazırlık olarak nitelendirmektedirler. Günlerinin büyük kısmını da ibadetle geçirmektedirler.

- "Yaşlanmak bizim için ilahi kanundur." (Hüseyin, Sancaktepe, Erkek, 65)

- "Yaşlanıyoz tabi hasta da oluyoz. Hastaliklarm neresine üzüleyim? Allah'a karşı gelmem. Allah veriyor, Allah iyi ediyor. Bir herkesi iyi ediyor, bir yatırtyor. Imtihandır hastalk. Allah'tan geliyor." (Sakine, Sancaktepe, Kadın, 77)

Şişli'de ise görüşülen kişilerin pek azı kendini dindar olarak nitelendirmiştir. Bu kişilerin yaşlılık algısı ve yaşlılıkta ortaya çıkan negatif durumlarla baş etme konusunda dini referanslar vermedikleri gözlemlenmiştir.

\section{Yalnızlık}

Araştırma sorusu belirlenirken kimliği oluşturan temel faktörlerden birkaçı olan sosyo-ekonomik statü, yaş aralığı, gelir ve eğitim durumunun bireyin yaşlılık algısını olumsuz yönde etkileyebileceği, bu faktörlerin kentli yaşam biçimi ile kesişimindense yalnızlık kavramının ortaya çıkacağı düşünülmüştü. Literatür çalışması da bu düşünceyi destekler nitelikteydi. Ancak özellikle geleneksel bir yaşam biçimi sürdüren, kentli yaşam biçiminden de görece kopmamış olan Sancaktepelilerden alt sosyo-ekonomik statüdeki bireylerin ifade ettikleri bu düşünceyi çürütmüştür. Sancaktepe'deki dindar ve geleneksel toplum yapısı, samimi aile ve komşuluk ilişkileri, ilçede yaşayan alt sosyo-ekonomik statüdeki bireyin görece mutlu bir yaşlanma süreci deneyimlediğini göstermiştir. Bununla beraber, mahalle kültürünün süregeldiği ilçede yaşlı birey çocukları ve torunları ile beraber geleneksel aile yapısını devam ettirmektedir. Görüşülen kişiler ailerinden, akrabalarından, mahalledeki komşularından saygı gördüklerini belirtmişlerdir. Günlerinin çoğunu bu kişilerle geçirdiklerini ve neredeyse hiç yalnız kalmadıklarını ifade etmişlerdir. Bununla beraber Şişli'dekilere göre görece dindar olan Sancaktepeli yaşlıların yaşlılık ile ilgili fikirleri daha olumlu yöndedir. Oysa Şişli' de durum tam tersidir. Aile ve komşuluğa dayalı ilişkilerinin yoğun olmadığı Şişli'de yaşlılar, yalnızlık sorunu ile karşı karşıyadırlar. Kimileri günlerce kimseyi görmeden ve konuşmadan evde yalnız kaldıklarını, kimileri de çocukları ve torunlarını özlediklerini ve onları uzun süre görmedikleri için mutsuz olduklarını dile getirmişlerdir. 
Yakınların kaybı araştırmanın önemli bulgularından biridir ve yalnızlık bulgusuyla yakından ilişkilidir. Her iki ilçede de katılımcların büyük bir kısmı yakınlarının kayıplarından dolayı duydukları üzüntüyü, kayıp sonrası yalnızlık ile ilişkilendirmişlerdir. Bu bulgu cinsiyet, sosyo-ekonomik statü ve yaş aralığı fark etmeksizin yakınlarını kaybeden tüm katılımcılar için geçerlidir.

- "Yaşlanınca evde tek başıma yaşamaya başladım; 75 senesinden beri. Annemi kaybettik, babamı kaybettik... Tek başıma kaldım." (Perihan, Şişli, Kadın, 85)

- "Yaşlandikça kayıplar oluyor tabi... Bir de biraz yalnız hissediyorum kendimi, eşimi kaybettikten sonra daha çok yalnızım.... Etrafimda eşim dostum yok... Kalanlar tabi, ölenler öldü." (Hulusi, Sancaktepe, Erkek, 83)

Görüşülen katılımcının eşini ya da birinci dereceden başka bir yakınını kaybetmiş olma durumu yalnızlaşmanın katmerleşmesi ve o katılımcının toplumun diğer üyeleriyle etkileşiminin neredeyse bitişi ile sonuçlandığı görülmüştür. Söz konusu duruma Şişli'de görüşülen kişilerde daha çok rastlandığı ortaya çıkmıştır.

- “...Ailesini, insanın özellikle kardeşini kaybetmesi (yutkunuyor) çok daha farklı bir olay. İnsanı çok etkileyen... Ölümlerden ders aldığıma inanıyorum, insanlık bakımından. Yani bakış açım değiş̧ti..." (Mülkiye, Şişli, Kadın, 65)

- "Eşimi kaybettim kızım. Bir yanım eksik.." (Süleyman, Sancaktepe, Erkek, 80)

\section{Tartışma ve Sonuç}

Gençlerin, yetişkinlerin ve yaşlıların yaşlanma hakkındaki düşünceler farkl1lık göstermektedir. Geleneksel toplumlarda yaşlılar saygı duyulan bir konumdayken modernite ile bu durum değişme eğilimindedir. Öte yandan toplumsal yapının değişimi yaşlıya bakışı da dönüştürmüştür. Kırdan kente göç, kentleşme, sanayileşme, geniş aileden çekirdek aileye geçiş gibi değişime neden olan gerçekler, günden güne hızla artış gösteren demografik yaşlanma ile birlikte düşünüldüğünde, yaşlının toplumsal konumlanışını araştırmak önem arz eden konuların başında gelmeye başlamıştır.

$\mathrm{Bu}$ araştırmada bir toplumsal grup olan yaşlıların yaşlılık deneyimlerini şekillendiren etkenler ve bunların kesişimselliği üzerinde durulmuştur. Yaşlı bireyin sosyo-ekonomik statüsü, eğitim durumu, yaşam biçimi, gelenek- 
sel/modern ayrımı; yaşlılık sürecini etkileyen faktörler olarak ortaya çıkmıştır. Araştırmanın bulgularında, küresel bir kent olan İstanbul'un demografik özellikleri bakımından karşılaştırılan iki ilçesi Sancaktepe ve Şişli'de yaşayan yaşlıların söz konusu faktörler sonucunda farklı yaşlılık deneyimlerine sahip oldukları sonucuna ulaşılmıştır. Buradaki farklılaşma yaşlılık deneyimi, yalnızlık ve geleneksellik olmak üzere üç tema altında toplanmıştır. Geleneksel toplumlarda yaşlılara atfedilen saygın rol, yine bir geleneksel toplum örneği sergileyen Sancaktepe'de de kendini göstermiş, Sancaktepeli yaşlıların çoğu Şişli'dekilere göre kendilerini daha mutlu hissettiklerini dolayısıyla yaşlılık deneyimlerinin olumlu olduğunu ve yaşllı̆ğın getirebileceği fiziksel, ruhsal ve maddi olumsuzluklarla daha kolay baş ettiklerini belirtmişlerdir.

Öte yandan Şişli'de yaşayan özellikle üst ve orta üst sosyo-ekonomik statüden yaşlılar Sancaktepe' dekilere göre daha aktif bir yaşlılık süreci geçirdiklerini belirtmiş ancak çocukları ve torunlarından uzak oldukları için daha yalnız ve görece daha mutsuz bir yaşlılık süreci deneyimlediklerini söylemişlerdir. Buna ek olarak yaşadıkları apartmanlardaki çoğu dairenin işyeri olması nedeniyle seyrekleşen komşuluk ilişkileri nedeniyle görece olumsuz bir yaşlılık deneyimi yaşadıklarını belirtmişlerdir. Oysa Sancaktepe'de yaşayan alt sosyo-ekonomik statüden yaşlılar, birarada yaşadıkları akrabaları ve/veya komşuları ile bir dayanışma örneği gösterdiklerinden gelir ve pahalılık konularına neredeyse hiç değinmemişlerdir. Dolayısıyla, yaşlılık ve yalnızlık kavramları arasında da kesişimsel bir ilişki mevcuttur. Şişli örneğine bakıldığında kentleşme ve/veya kentlileşme kavram(lar)ının da yaşlılık sürecini etkilediği görülmüştür. Sancaktepe ile karşılaştırıldığında kentleşme/kentlileşme sürecinde daha ileride olan Şişli'de orta ve alt sınıf yaşlılar, gelir durumu ve harcamalarındaki orantsızlık nedeniyle pahalılıktan dert yanmışlardır.

Yaşam evrelerinin sonuncusu olan yaşlılık, bireysel bir kavram olmasının yanı sıra toplumsal yeniden üretimin devam ettiği bir süreçtir. Yaşlılar da bir toplumsal grup olarak tanınmalıdır. Bu makalede ele alınan kavramsal çerçeve geleneksellik, yalnızlık ve sosyo-ekonomik statü değişkenlerinin yaşlılık süreci üzerindeki etkisini araştırmaya yöneliktir. Bu üç kavramın birbiri ile ve ayı zamanda yaşlılık süreci ile kesişimselliği yaşlılık deneyiminin her birey için biricik olma özelliğini de ortaya çıkarmaktadır. 


\title{
EXTENDED ABSTRACT
}

\section{Yaşlılık Deneyimi ve Kesişimsellik: İstanbul Örneği}

\author{
Berfin Varışl1 \\ Maltepe Üniversitesi
}

The population of Turkey is aging. As in many provinces of the country, the density of the elderly population in Istanbul is also rapidly increasing. On the other hand, the geographical positioning of Istanbul, which can be described as "in between" Asia and Europe, has many social and cultural reflections. Istanbul, with its multicultural structure can be seen as an example of Turkey's cultural mosaic.

Based on the intersection of the urbanisation and the old age, this study focuses on the differentiation of experiences of elderly people living in Sancaktepe and Şişli districts of Istanbul. The reason why Şişli and Sancaktepe districts were chosen for the field study of the research is that the individuals living in these two districts are socio-economically and socio-culturally different and distinct. Şişli is a district with an urbanised history where mostly middle and upper-class, educated, non-Muslims and Muslims live together; on the other hand Sancaktepe is a district, inhabited by Sunnis and Alevis from the lower and middle class, living a traditional life. Most of the people living in Şişli were born and raised in Istanbul, while most of the people living in Sancaktepe migrated to the district from different parts of Turkey.

The sample of the study was composed of Istanbulites over 65 years of age living in Sancaktepe and Şişli, who differ in lifestyle, worldview and socioeconomic and educational status. In this study, a qualitative research was conducted, 45 in-depth interviews were made, and the interviewees were reached using the snowball technique.

Three neighborhoods were selected from both districts and the individuals living in these neighborhoods were categorized according to their socioeconomic status. Age ranges determined by the World Health Organization were observed in the age classification, interviews were conducted with age groups of 65-74, 75-84, 85 and above. 
In the results of the study, it was concluded that the elderly living in Sancaktepe and Şişli districts, had different old age experiences. The differentiation here has been analyzed in terms of socio-economic status-old age experience, traditional/modern distinction, urbanization and loneliness.

The findings firstly reveal how important traditionalism and modernity are in the life of the elderly people. It has also been found that the experience of old age is closely related to social structure, habitus, and family relations. For example, individuals with higher socio-economic status and higher education levels, most of whom live in Şişli, undergo an active elderly experience. They avoid identifying themselves as elderly.

However, religious elders of lower and middle socio-economic status, most of whom live a traditional lifestyle in Sancaktepe, see old age as "a blessing given to them by God" and are grateful that they have lived for many years. Therefore, in Şişli and in Sancaktepe, differentiated social structures affected the individuals, changing the way the elderly perceive and express themselves. On the other hand, some of the highly educated participants from Şişli of middle and upper socio-economic status stated that old age is a natural stage of life such as childhood and adulthood. These participants associated old age with death, and although they did not pronounce the word death directly, they expressed that aging was a kind of preparation for death.

The respectable role attributed to the elderly in traditional societies has also manifested itself in Sancaktepe, and most of the elderly people, who are living in this district stated that they feel much happier than those in Şişli, therefore their old age experiences are positive and fulfilling. They cope more easily with the physical, spiritual and material negativities that old age can bring. On the other hand, elderly people living in Şişli, especially from the upper and middle socio-economic status, stated that they had more active and successful old age experience/process than those in Sancaktepe, but they stated that they experienced a lonelier and relatively unhappy old age experience. According to their point of view, the reason behind an unhappy elderly experience was their distant relationship with their children and grandchildren. However, elderly people of lower socio-economic status living in Sancaktepe indicated an example of solidarity with their relatives and/or neighbours in which they live together, therefore, there is also an intersectionality between the concepts of old age and loneliness. 
The conceptual framework discussed in this article is aimed at investigating the impact of traditionalism, loneliness and socio-economic status variables on the old age process. The intersection of these three concepts with each other and with the process of old age also reveals the fact that the experience of old age is unique for each person.

\section{Kaynakça / References}

Barna, G. (2002). The state of the church. Ventura, CA: Issachhar Resources.

Blazer, D. ve Palmore, E. (1976). Religion and aging in a longitudinal panel. The Gerontologist, 16(1/1), 82.

Bourdieu, P. ve Wacquant, L. J. D. (2003) Düşünümsel bir antropoloji için cevaplar. N. Ökten (Çev.) İstanbul: İletişim.

Bourdieu, P. (1997). Toplumbilim sorunları. I. Ergüden (Çev.) İstanbul: Kesit.

Crenshaw, K. W. (1991). Mapping the margins: intersectionality, identity politics and violence against women of color. Stanford Law Review 43(6), 1241-1299.

Davie, G. ve Vincent, J. (1998). Religion and old age. Ageing and Society, 18(01), 101110.

ITO [İstanbul Ticaret Odası] (2011). İstanbul'da yaşam kalitesi araştırması. İstanbul: İstanbul Ticaret Odası.

Kalaycıoğlu, S., Tol, U. U., Küçükural, Ö. ve Cengiz, K. (2003). Yaşlılar ve yaşlı yakınları açısından yaşam biçimi tercihleri. Türkiye Bilimler Akademisi Raporlari, 5, 7-31.

Keyder, C. (2005). Globalization and social exclusion in Istanbul. International Journal of Urban and Regional Research, 29(1), 124-134.

Settersten Jr, R. A. ve Mayer, K. U. (1997). The measurement of age, age structuring and the life course. Annual Review of Sociology, 23(1), 233-261.

Taylor, R. J. (1986). Religious participation among elderly blacks. The Gerontologist, 26(6), 630-636.

TÜIK [Türkiye İstatistik Kurumu]. (15.12.2018). İstatistiklerle yaşllar. https:/hsgm.saglik.gov.tr/depo/birimler/kronik-hastaliklar-engelli$\mathrm{db} /$ hastaliklar/Yasli Sagligi/raporlar istatistikler/TUIK Yasli Istatistik 2018.pdf adresinden erişildi.

United Nations. (29.06.2017). World Population Ageing Highlights https://www.un.org/en/development/desa/population/publications/pdf/ageing/WPA2017 Highlights.pdf adresinden edirişildi. 


\section{Kaynakça Bilgisi / Citation Information}

Varışlı, B. (2020). Yaşlılık deneyimi ve kesişimsellik: İstanbul örneği. OPUS-Uluslararası Toplum Araştırmaları Dergisi, 16(30), 2551-2567. DOI: 10.26466/opus.693033 